\title{
Možnosti a rizika využití otevřených vzdělávacích zdrojů v environmentálních oborech na vysokoškolské úrovni v ČR: kritéria pro posouzení kvality
}

\author{
Jana Dlouhá, Eduard Petiška, Jiří Dlouhý, Dana Kapitulčinová \\ Envigogika 10 (4) - Recenzované články/ Reviewed Papers/ \\ Publikováno/Published dne 5. 12. 2015
}

DOI: $\underline{10.14712 / 18023061.503}$

\begin{abstract}
Abstrakt
Prosazování otevřených vzdělávacích zdrojů (OER) v dokumentech i praxi na různých úrovních souvisí mj. s možnostmi, které tyto zdroje nabízejí při studiu, sdílení, a poprípadě společné tvorbě souborů informací a poznatků, což má významné dopady na ekonomiku znalostí, ale i způsoby jejich vytváření a reprodukce ve vzdělávání. Článek představuje koncept OER s ohledem na jeho zakotvení v legislativě (problematika copyrightu), roli v celosvětových závazcích $\mathrm{k}$ udržitelnému rozvoji, a zejména souvislosti s pedagogickými př́stupy $\checkmark$ procesu jejich současné proměny a vývoje; poukazuje na inovační potenciál OER pro multidisciplinární obory životního prostředí a UR. Podává stručný přehled typů OER, které jsou $v$ ČR k dispozici otevřenou formou pro studium oborů ŽP a UR, s využitím kvalitativní metody provádí jejich analýzu a navrhuje soubor kritérií, podle kterých Ize jednoduše usuzovat na kvalitu daného zdroje. Hodnotí různé typy OER (po 3 v několika skupinách) podle těchto kritérií a diskutuje celkovou povahu informačního prostředí, jak se studentům vysokých škol nabízí. Přehled o situaci OER je uzavřen konstatováním značných př́ležitostí zvláště v oblasti ŽP a UR, které souvisí s multidisciplinární povahou těchto oborů; tyto možnosti však nebývají naplněny především pro nesnadné rozlišení kvality zdroje v prostředí internetu, ale pravděpodobně i neschopnost samotných studentů takovou kvalitu posuzovat a možná i všeobecnou nedůslednost vysokoškolských učitelů při prosazování etických norem při studiu.
\end{abstract}

\section{Klíčová slova}

Otevřené vzdělávací zdroje; vysokoškolská výuka; environmentální obory; interdisciplinární souvislosti; hodnocení kvality

\begin{abstract}
The expansion of open educational resources (OER) in documents and practice at various levels is related to, among other things, the options these resources offer for the study, sharing, and possibly joint creation of information materials. This has important implications for the knowledge economy, but also the ways of its production and reproduction in education. The article introduces the concept of OER from a legislative perspective (copyright issues), its role in global commitments to sustainable development and particularly in relation to the teaching/learning methods and approaches in the process of their current transformation; the innovative potential of OER for the multidisciplinary field of environment and
\end{abstract}


sustainable development is highlighted. A brief overview of the types of OER which are available in the Czech Republic for the study of environmental and sustainability fields is provided, and qualitative methods of analysis are used to develop a set of criteria through which the quality of the resource can be easily assessed. Different types of OER are evaluated according to these criteria and the overall character of the information environment available to university students is discussed. This brief overview is concluded by underlining significant opportunities of OER particularly in the environment and sustainability oriented disciplines owing to the multidisciplinary nature of these fields. These opportunities, however, are not fully exploited especially because the quality of these resources available on the internet is difficult to assess. Another issue is also the possibility that students themselves are not skilled in distinguishing the quality of resources, and perhaps the reluctance of university teachers to encourage and support students in applying consistent ethical standards in their use of materials in their studies.

\section{Key words}

Open education resources; higher education; environmental disciplines; interdisciplinarity; quality assessment 


\section{Úvod}

Otevřené vzdělávací zdroje (anglicky Open Educational Resources - OER) jsou volně přístupné, otevřeně licencované dokumenty a média, která jsou využívána pro výuku, učení a hodnocení, jakož i pro výzkumné účely. Jejich vznik je důsledkem ",hnutí za otevřenost", které se snaží o změnu př́stupů $v$ oblasti distančního, resp. otevřeného a distančního vzdělávání (Bozkurt et al., 2015). Rozvoj a podpora otevřených vzdělávacích zdrojů jsou v tomto smyslu motivovány touhou omezit komodifikaci znalostí a prosadit alternativní či vylepšené vzdělávací paradigma (Kauppinen, 2014).

Právě snaha uvolnit poznatky a informace z panujících ekonomických vztahů hraje roli v oblasti udržitelného rozvoje, kde je možno sledovat souvislost mezi využitím OER a právě přijatými Cíli udržitelného rozvoje (angl. Sustainable Development Goals, SDGs). Několik dílčích bodů - úkolů - navrhovaných cílů, zmiňuje právo na vzdělání pro všechny, a dále právo na informace a využití informačních a komunikačních technologií (ICT). Role OER $\checkmark$ tomto kontextu otevírá možnosti vzdělání a přistup k relevantním informačním zdrojům, což potom má nezanedbatelný vliv na budoucí ekonomické př́ležitosti - a tedy i význam při řešení globálních rozvojových problémů či otázek udržitelného rozvoje. $Z$ tohoto důvodu například Commonwealth of Learning a UNESCO podporují využití OER v rozvojových zemích (Willems \& Bossu, 2012), kde mají pomoci překonat nedostatek vzdělávacích príležitostí a také informačních zdrojů (Richter \& McPherson, 2012). Aktivity, které se $v$ rámci SDGs procesu v současné době rozebíhají na mezinárodní i národní úrovni, tak směřují mj. k zajištění široké dostupnosti kvalitního vzdělání a podpoře technologického rozvoje či transferu technologií, a to především ve vztahu k udržitelnému využívání přírodních zdrojů, což jsou významné prvky rozvojové agendy. Podrobnosti o samotných SDGs a začlenění OER $v$ jejich rámci uvádíme pro přehlednost až na konci tohoto textu (viz Př́loha 1).

Jak dále uvidíme, OER mají také vliv na proměnu procesů výuky/učení směrem k jejich větší otevřenosti a demokratizaci (založené mj. na změně vztahu mezi učitelem a studentem); jelikož tato proměna je též jedním z požadavků vzdělávání pro udržitelný rozvoj (VUR), budeme se jí hlouběji zabývat $v$ tomto článku. Argumentujeme zde, že jde o celkovou proměnu vzdělávacího prostředí, na kterou má povaha a kvalita materiálů pro studium zásadní vliv.

\section{Vymezení problému}

Lze najít mnoho různých definicí Otevřených vzdělávacích zdrojů (i v češtině budeme nadále užívat označení OER) (Creative Commons, 2015b). Termín byl poprvé použit na fóru "Open Courseware", pořádaném UNESCO v roce 2002, kde byly OER označeny jako "výukové, učební a výzkumné materiály na jakémkoliv médiu, v digitální či jiné podobě, které jsou licencovány jako veřejné vlastnictví nebo pod jinou otevřenou licencí, která umožňuje neplacený přístup, používání, adaptaci a další šiření dalšími uživateli bud' zcela, nebo s omezeným omezením. Otevřená licence je postavena ve stávajícím rámci práv duševního vlastnictví dle př́slušných mezinárodních úmluv a respektuje autorství práce". Často je také citována definice Nadace Williama a Flory Hewlettových (Hewlett Foundation, 2015), která definuje OER zdroje pro:

„....výuku, učení a výzkumné zdroje, které jsou ve veřejném vlastnictví, nebo byly vydány pod takovou licencí duševního vlastnictví, které umožňuje jejich volné použití a opětovné modifikace ostatními uživateli. Otevřené výukové zdroje zahrnují veškeré 
kurzy, studijní materiály, moduly, učebnice, streaming videa, testy, software a jakékoli jiné nástroje, materiály nebo techniky používané na podporu prístupu ke znalostem".

K prvnímu výraznému využití otevřených vzdělávacích zdrojů došlo na univerzitě $\checkmark$ Tübingen $v$ Německu $v$ roce 1999; masově byly OER nasazeny na americké univerzitě MIT $\checkmark$ roce 2002, a posléze se staly celosvětovým fenoménem. Postupně vzniklo několik iniciativ na jejich podporu, např́klad Kapská deklarace (Cape Town Open Education Declaration) z r. 2007, kterou již podepsalo 2518 jednotlivců a 258 organizací, nebo všeobecná Pařížská deklarace UNESCO o OER. Hodnota široké dostupnosti otevřených vzdělávacích zdrojů je uznána Radou Evropy (Doporučení 1836, 2008) jako prostředek řešení digitální propasti a poskytování kvalitních vzdělávacích zdrojů všem; UNESCO podporuje OER protože mimo jiné pomáhají naplňovat základní právo na vzdělání (Kolektiv autorů, 2012).

Také $v$ českém prostředí se postupně rozbíhají debaty o zavedení otevřených vzdělávacích zdrojů; jejich používání je podporováno i ze strany státní správy: jsou zmíněny např. ve Strategii digitálního vzdělávání do roku $2020^{1}$ a Strategii digitální gramotnosti². V praktické rovině jsou součástí vnitřní politiky některých vysokých škol (jak ji prosazuje např. Masarykova univerzita, nebo Univerzita Karlova v Praze); nevládní organizace se snaží tento princip uplatňovat již delší dobu. $V$ současné době o systémové zavedení tohoto přistupu $v$ ČR usiluje tzv. Aliance pro otevřené vzdělávání ${ }^{3}$, která vytváŕí sít příznivců otevřeného vzdělávání v ČR ( $v$ době psaní článku měla již více než osmdesát podporovatelů), a snaží se napojovat se na mezinárodní dění ${ }^{4}$. Má rovněž ambice působit na vzdělávací politiky a $\mathrm{k}$ tomuto cíli vytvořila Chartu otevřeného vzdělávání ${ }^{5}$, jejímž cílem je stručně shrnout principy OER a získat pro jejich využivání co nejširší podporu.

V poslední době se zdá, že téma OER začíná získávat pozornost, kterou si zasluhuje. Otázka tak již nestojí, proč by se měly tyto zdroje vůbec používat; ptáme se zde především, jaké jsou př́nosy či negativa jejich využití, a to z hlediska různorodosti forem a obsahů OER. $S$ rozvojem internetu totiž postupně vzniklo mnoho úložišt́ otevřených materiálů, které se velmi liší svými základními vlastnostmi (například možnostmi vyhledávání pomocí metadat) a obsahují zdroje různé šíre i kvality. $\mathrm{K}$ takto položení otázce patří též zájem o možné způsoby používání OER (doporučené a reálně existující v praxi) a jejich (ne)vhodnost zvláště pro obory životního prostředí a UR. Problém budeme zkoumat na úrovni vysokých škol, kde často vznikají vzdělávací materiály též pro nižší stupně; v mnoha ohledech jsou tak univerzity či jejich učitelé "průkopníky" v této oblasti. Pokusíme se zde pojmenovat potenciální prínosy a rizika online zdrojů, a to tak, aby pozitivní rysy mohly být co nejlépe využity, kdežto vliv druhých byl v nejvyšší možné míre potlačen, alespoň co se týká kvality procesů

\footnotetext{
${ }^{1}$ Strategie byla schválena vládou v listopadu 2014; mj. říká: „Bude v něm zajištěn přístup ke sdílené vzdělávací infrastruktuře (...) a ke kvalitním vzdělávacím zdrojům (otevřeným vzdělávacím zdrojům, digitálním učebním materiálům a dalším zdrojům, které Ize pro vzdělávání využít)."

2 vládou schválená v červenci 2015

${ }^{3} \mathrm{~V}$ červnu 2015 se téměř tři desítky podporovatelů otevřeného vzdělávání z různých institucí sešly, aby společně probraly, jak co nejlépe uskutečňovat podporu a propagaci otevřeného vzdělávání jako významné možnosti snižování nerovností v přistupu ke vzdělávacím zdrojům. Jako jeden z prvních cílů aliance má být ovlivnění harmonizace autorského práva v zemích Evropské unie. Viz http://www.ceskaskola.cz/2015/09/ondrej-neumajer-otevrene-vzdelavani.html

${ }^{4}$ Např́íklad formou sdílení zkušeností s tvorbou a správou úložišté kvalitních vzdělávacích materiálů na evropské úrovni (http://www.klascement.net/?hl=en, http://ndla.no/

${ }^{5}$ Prozatímní odkaz: https://docs.google.com/document/d/1c9Z AfO2d6vBQNDZGksoCKjtZhyOApE9GJaSkGTgNM/edit?pli=1
} 
výuky/učení, které by na nich mohly být postavené. Mezi těmito vlastnostmi chceme najít ty, které jsou zvláště vhodné pro mezioborovou povahu environmentálních oborů (a případná jejich další specifika), což by mohlo naznačit možnosti inovace procesů výuky/učení a prípadně též celkovou změnu pohledu na vzdělání v této oblasti.

V souladu s analýzou různých definic OER, kterou provedl (Camilleri, Ehlers, \& Pawlowski, 2014), se v tomto výzkumu budeme zabývat takovými otevřenými zdroji, jež jsou $\checkmark$ digitální podobě otevřeně přístupné na internetu, přičemž to, zda je Ize považovat za vzdělávací materiály (OER) bude teprve předmětem diskuse. Zmínění autoři na základě různorodého způsobu vymezení OER určili jejich společné (a na druhé straně rozdílné) charakteristiky: mezi sporné rysy patř́ původ zdroje (relevance pro vzdělávání), úroveň otevřenosti, a typ zdroje; společné znaky pak zahrnují možnost jejich neomezeného využití, a to bez poplatku, a dále digitální povahu (viz též Kapitulčinová, Spustová, Nemcová, \& Petiška, 2016 v prípravě). Digitální či online povaha OER materiálů je zdůrazňována též ve zprávách Evropské komise (High Level Group on the Modernisation of Higher Education, 2014) nebo (OECD, 2007)

\section{Právní vymezení OER - autorské licence}

Pro lepší pochopení šíře možností pro sdílení materiálů formou OER je můžeme rozdělit do několika typů podle obsahu, nástrojů a implementačních zdrojů vhodných pro efektivní vytváření a šiřrení OER mezi další uživatele (viz Příloha 2).

Pro vymezení samotného pojmu "otevřené vzdělávací zdroje" je velmi důležitá legislativní otázka autorského práva, která je řešena pro OER nově vyvinutými autorskými licencemi, jež představují možnost do určité (přesně specifikované) míry uvolnit autorská práva pro některé způsoby využití autorských materiálů, přičemž je autorství plně zachováno. $\checkmark$ praxi se používají různé licence, zdaleka nejrozšířenější a nejpropracovanější jsou licence Creative Commons, které jsou souborem veřejných licencí, přinášejících "nové možnosti v oblasti publikování autorských děl: posilují pozici autora při rozhodování, za jakých podmínek bude dílo veřejně zpř́stupněno. Licence Creative Commons fungují na jednoduchém principu: autor jejich prostřednictvím nabízí neurčitému počtu potenciálních uživatelů licenční smlouvu, na základě které jim poskytuje některá svá práva $\mathrm{k}$ dílu a jiná si vyhrazuje." (Creative Commons, 2015a). Tyto licence mají navíc celosvětově jednotný systém, který umožňuje uživatelům jednoduše posoudit možnosti využití zdroje $i$ v prípadě zahraničních děl, a ve vyspělých státech včetně ČR existuji národní „portace”, tedy přesná právní definice dané varianty licence vzhledem $\mathrm{k}$ národním zákonům. Creative Commons tak nejsou popřením klasického pojetí autorského práva, jsou jeho nadstavbou a jako takové vycházejí v České republice z občanského zákoníku (§ 2358 - 2389 Zákona č. 89/2012 Sb., občanský zákoník). Přehled užívaných licencí CC a jejich charakteristiky viz Příloha 3.

Autorské licence hrají roli při budování důvěry mezi těmi, kdo vytvářejí a používají OER. V souvislosti s vysokoškolským vzděláváním je třeba zmínit, že Strategie digitálního vzdělávání do roku 2020 ukládá učitelům i studentům posilování právního vědomí a znalostí autorského práva při používání OER.

\section{Využití OER pro výuku environmentálních oborů na vysokých ško- lách}

Koncept otevřeného vzdělávání vznikl na půdě vysokých škol a od počátku nového milénia je zde rozvíjeno největší množství aktivit v souvislosti s OER; platí přitom, že OER 
přináší samotným vysokým školám konkurenční výhody v podobě zvýšeného zájmu studentů (dobré vzdělávací materiály publikované online jsou určitou formou PR (Caswell, Henson, Jensen, \& Wiley, 2008). V současnosti jsou OER pokládány především za relativně levný prostředek ke zlepšení kurikula a zvýšení celkové efektivity vzdělávání: do budoucna se díky zvýšení využití online a otevřeného vzdělávání počítá se všeobecným rozšiřením přístupu k vysokoškolskému vzdělávání a jeho širším dopadem na různé skupiny studentů (např. $\checkmark$ rámci celoživotního vzdělávání a profesního rozvoje). Tak se na to dívá řada mezinárodních organizací, které otevřené vzdělávací zdroje podporují, např́íklad UNESCO, COL, OECD, Evropská unie a další (Kanwar, Uvalić-Trumbić, \& Butcher, 2011). Zpráva pro Evropskou komisi (High Level Group on the Modernisation of Higher Education, 2014) pak z tohoto důvodu apeluje na vlády a veřejné autority, aby $v$ rámci modernizace vysokého školství zabezpečily podmínky a prostředky na rozvoj a podporu online vzdělávání, včetně jeho inovativních forem, např́iklad s využitím OER. Doporučení k OER určená hlavním aktérům ve VŠ vzdělávání - jako jsou národní vlády, vysokoškolské instituce, akademičtí pracovníci, studentská uskupení a instituce zabývající se kvalitou a akreditacemi VŠ vzdělávání - předkládá publikace Guidelines for Open Educational Resources (OER) in Higher Education (COL \& UNESCO, 2011). OER mohou ovšem přinést značnou konkurenční výhodu samotným vysokým školám: jde o zkušenost založenou na poznatku, že znalosti samy o sobě nejsou použitelné, pokud chybí dovednosti s nimi pracovat, a tedy OER mohou přitáhnout zájem (a tedy i dobré studenty) výjimečným osobnostem a jejich institucím (Caswell et al., 2008).

Zájem o "otevřenost" v oblasti životního prostředí ovšem vychází z poněkud jiné filosofie: souvisí s tradicí a kulturou otevřenosti založenou na vzájemné podpoře, sdílení informací a zkušeností, kterou $v$ rané fázi celosvětového environmentálního hnutí formulovala Aarhuská úmluva6 (ratifikována ČR v r. 2004) zaručující všeobecné právo na informace o životním prostředí - výslovně proto, že "mají-li občané uplatňovat toto právo [na zdravé životní prostředí] a dostát této povinnosti, musí mít přístup $\mathrm{k}$ informacím o životním prostředí".

\section{Relevance OER z hlediska environmentálních oborů}

Je tak možné sledovat styčné body mezi otevřeným prostředím (využívajícím OER) a obecným principem otevřenosti, participace, a to $v$ obsahu i formách výuky. Tyto principy jsou zvláště relevantní pro environmentální studia, která nejsou vědní disciplínou v klasickém slova smyslu. Termín "studia životního prostředí označuje komplexní propojení více vědních oborů, integrační koncept popisující vztahy a interakce člověka s jeho prostredím. Porozumění problémům $v$ oblasti životního prostředí vyžaduje schopnost využít poznatků z mnoha oblastí, ale také pochopit vzájemné vztahy mezi jevy a př́slušnými oborovými pohledy. Environmentální studia tak ze své podstaty musí být interdisciplinární, resp. transdisciplinární, protože pouze kombinací různých poznatků a přístupů je možné dosáhnout nové úrovně v integraci znalostí (Caldwell, 1983).

Pro naplnění výše popsaných cílů environmentálních studií jsou podle posledních výzkumů velmi vhodné určité elektronické prostředky, které zohledňují propojení různých disciplín a Ize je využít při studiu i výzkumu. Jak ukázali (Ziegler, Webb, Norton, Pullin, \&

${ }^{6}$ Viz např. http://www.ucastverejnosti.cz/cz. Aarhuská úmluva má 3 pilíře, z nichž jeden zaručuje právo na informace o životním prostředí, kde se "Strany [Úmluvy zavazují, že] budou podporovat environmentální osvětu a vzdělávání veřejnosti, zejména o tom, jak získat prístup k informacím, jak se účastnit na rozhodování a jak získávat přístup k právní ochraně v záležitostech životního prostředí." 
Melcher, 2015), právě online prostředky s otevřeným přístupem (Open Access) umožňují efektivně využít detailní výsledky jednotlivých oblastí výzkumu problematiky životního prostředí a začlenit je do efektivního systému, který usnadní hledání souvislostí mezi dílčími, často málo využívanými výsledky výzkumu. Využívání otevřeného př́stupu není totožné s prostým sdílením primárních dat, na druhou stranu však pomáhá účinnějšímu využívání primárních znalostí. Jak uvádějí výše zmínění autoři, tyto prostředky jsou stále častěji užívány díky současnému rozvoji informačních technologií a také vlivem nastupující on-line kultury projevující se též ve vědě např. postupným šířením croudsourcingu a občanské vědy (srv. (Wals, Brody, Dillon, \& Stevenson, 2015). Takto zveřejněné výsledky mohou dále využivat jak vědci, tak také třeba pracovníci s rozhodovacími pravomocemi. Výsledná díla Ize využívat mnoha způsoby - pro zvyšování efektivity a včasnosti systematických hodnocení, pro hodnocení životního prostředí, metaanalýzy, identifikaci nedostatků ve znalostech, ke hledání výzkumných přiležitostí či při zkoumání spojitostí mezi výsledky výzkumu a stavem životního prostředí.

\section{Relevance OER z hlediska nových pedagogických přístupů}

Povaha materiálů využívaných ve výuce ovšem proměňuje též samotný vzdělávací proces, a to jak z pohledu studentů, tak vzdělavatelů. OER jsou součástí širšího trendu digitalizace vzdělávání; instituce COL a UNESCO v souvislosti s jejich zaváděním hovoří nejen o ekonomických prínosech, ale též o rozvoji individuálního vzdělávání a inovací v pedagogice nebo o nových možnostech profesního rozvoje vyučujících, a to při vytváření a užívání kvalitních a efektivních výukových materiálů (Kanwar et al., 2011), (COL \& UNESCO, 2011). OER aktivně vstupují do vzdělávacího prostředí a modifikují jej, činí ho otevřenějším, a to pak ovlivňuje způsoby komunikace či interakce mezi aktéry vzdělávání, jejich vztahy a role (Atkins, Brown, \& Hammond, 2007). Přirozeně dochází k určité transformaci procesů učení, a pokud se nevěnuje pozornost předpokladům nezbytným pro tento vývoj, zavádění OER může být nesystémové a odsouzené k nezdaru.

Jedním z argumentů na podporu OER je fakt, že v současném systému vzdělávání se student často setká se zdroji, které „nerespektují vstupní vědomosti, dovednosti a zkušenosti studujícího. Proto pak musí v určitých částech procházet známými informacemi [...]"

(Nocar, 2004). OER tento krok eliminují a umožňují studujícímu cíleně a snadno vyhledávat informace relevantní $k$ jeho předmětu zájmu - takové, které staví již na existujících

Principy, které prosazuje komunita OER (Bissell, 2009):

1. Vzdělání může a mělo by být otevřené a volně přistupné. Což ve zde prosazovaném smyslu znamená, že znalosti se mohou sdílet, vyvíjet a přizpůsobovat měnícím se podmínkám a také $s$ ohledem na místní potřeby a místní kulturu.

2. Většina pedagogů a ostatních podporovatelů OER věŕí, že OER pomohou vylepšit vzdělávací systém a příležitosti pro vzdělávání. Vyučování a učení mají být tvưrčí procesy, bez zbytečných právních překážek.

3. Při využívání OER dochází ke stírání hranic, které tradičně oddělovaly tvůrce obsahu od jeho uživatelů. Např́iklad učitelé i studenti mohou být zapojeni jak do tvorby, tak do používání OER (J. S. Brown, 2008) - na tom jsou založeny nové pedagogické metody, způsoby komunikace a hodnocení.

4. OER se mohou pružně a průběžně vylepšovat $-\mathrm{s}$ ohledem na rychlost technologických změn a přibývající znalosti. Platí zde také ono pravidlo 5R, což umožňuje tvưrčí práci se zdroji - jejich úpravy a kombinace (Bissell \& Boyle, 2007). 
vědomostech studenta. Lze tedy $v$ daleko větší míře ponechat studentům autonomii ve vyhledávání vlastních zdrojů dle jejich specifických studijních potřeb.

\section{Nevýhody OER a environmentální hlediska}

Podmínkou těchto změn ve vzdělávání jsou určité předpoklady pro práci v ICT prostředí; rozvojem samotných ICT kompetencí (byt' specifických pro OER), jimž se věnují četné vzdělávací strategie a politiky, se ale $v$ tomto textu zabývat nebudeme. Nicméně tyto elektronické otevřené zdroje jsou často právě z důvodu nízké informační gramotnosti předmětem nedůvěry pedagogů: do nedávna platilo, že pro mladší generace je ovládání technologických novinek samožrejmostí zatímco starší učitelé nebývají na jejich využíváni připraveni (Prensky, 2009) (Trojan \& Trávníček, 2014). Někdy může jít dokonce o celkovou averzi k online prostředí: existují výzkumy ukazující, že př́lišné používání internetu může vést k určité formě závislosti (Chou, Condron, \& Belland, 2005). Tento nepřátelský postoj může souviset $\mathrm{s}$ celkovou nedůvěrou $\mathrm{k}$ technologiím, která se vyskytuje u části environmentalistů, jak dokládá např́íklad studie Branda a Fishera (Brand \& Fischer, 2013). Odpůrci elektronických zdrojů z řad pedagogů pak argumentují, že u soustavných uživatelů internetu se zhoršuji jejich sociální charakteristiky i studijní výsledky (Chen \& Peng, 2008). Protože další zátěž by mohla tento špatný vliv zhoršovat, je snahou vzdělavatelů spiše své žáky/studenty z virtuálního prostředí vyvádět, než jim poskytovat další př́ležitosti z něj čerpat. $\mathrm{S}$ touto nedůvěrou ze strany pedagogické veřejnosti se setkáváme výrazněji právě u zastánců životního prostředí, kteří v rámci výchovy/vzdělávání usilují o autenticitu zkušenosti a poznání: zdroje nalezené na internetu jakož i samotný proces hledání "nejsnadněji dostupné informace" zde mohou být považovány a priori za nedůvěryhodné. Stačí si v této souvislosti připomenout výzkum kolektivu Emilie Strejčkové (Strejčková, 1998) (Strejčková, 2005) (Kolektiv autorů, 2009) ( viz též Envigogika 1/1, 2006, rubrika Recenze). Technologie jsou zde ovšem posuzovány velmi všeobecně, nerozlišuje se mezi konkrétními aspekty jejich využívání. Používání ICT (čas trávený na počítači, při hraní počítačových her atd.) je tak pouze démonizováno, přičemž nové přiležitosti nebo přínosy pro vzdělávání, které tyto aktivity naopak nabízí, nejsou vůbec diskutovány. Snaha o překonání této nedůvěry je jedním z důvodů, proč se zde představený výzkum zabývá specificky environmentálními obory.

Při vyšším používání elektronických médií mohou mít vzdělavatelé také dojem, že ztratí kontrolu nad procesy učení, nemusí totiž mít prímou zpětnou vazbu, kterou zajištúuje osobní kontakt a debaty nad výukovými texty. Změna kultury učení, které se odehrává alespoň částečně ve virtuálním prostředí, se ovšem týká i většiny dalších aspektů vzdělávacího procesu, který musí hledat nové postupy a metody (viz Dlouhá \& Burandt, 2015). Jelikož základním předpokladem toho, že se informace postupně transformují v poznatky, je vzájemné vyjasňování pojmů, diskuse, interakce, musí se s těmito faktory počítat i ve virtuálním prostředí - jsou zde obzvláště důležité. Tyto specifické nástroje pro využití v praxi by měl učitel sám umět navrhovat (Zahradník \& Pachmanová, 2009). 


\section{Možné souvislosti se specifiky vzdělávání pro udržitelný rozvoj (VUR)}

Se vzděláváním pro udržitelný rozvoj (VUR) však souvisí četné dovednosti, z nichž některé jsou na VŠ úrovni pěstovány tradičně, jako schopnost samostatného (problémově orientovaného) výzkumu; některé jsou ovšem pro VUR specifické a tradiční oborová výuka je nerozvíjí. Zde Ize hledat novou roli OER, které mohou určité dovednosti pěstovat s velkou výhodou.

V souvislosti s rozvojem kompetencí, které mohou být OER podporovány, se tak hovoří napríklad o tom, že:

- Vstup do otevřeného informačního prostředí podporuje demokratizaci výuky, je v podstatně větší míře možno uplatnit vlastní kreativitu: texty Ize nejen konzumovat, ale vytvářet (a publikovat) vlastní. Při této tvorbě mohou navíc studenti různými způsoby spolupracovat, a to jak vzájemně, tak i s učiteli (postupy této spolupráce mohou např́klad simulovat zavedené publikační postupy - viz (J. Dlouhá \& kol., 2013). To vše rozvíjí širokou škálu kompetencí, které se studenti učí spolu se vzdělávacími obsahy. Používání OER může přinášet četné další výhody, především co se týče posílení sociálních aspektů učení (viz Hemetsberger, 2006) a sociálních kompetencí, které Ize velmi dobře využít v praxi udržitelného rozvoje (UR).

- Se snadným prístupem $\mathrm{k}$ informacím může stoupat celková úroveň znalostí, je ale třeba učit nové kompetence práce s nimi, například co se týče posuzování kvality zdrojů (J. Dlouhá, Dlouhý, \& Barton, 2010). Samotný výběr vhodných materiálů pro výuku ještě nenastartuje efektivní proces učení; zde platí, že zpưsob používání elektronických zdrojů musí být v souladu s jejich zvláštní povahou. Internet totiž nelze považovat za jakousi „knihovnu”, ale spíše za interaktivní médium, což přináší zřejmé výhody, ale i nevýhody: texty a materiály sem pouze „pověšené" jsou do značné míry mrtvé, a mohly by takto umrtvit též výuku. Předpokladem efektivní výuky je tak především vhodné a přiměřené využití tohoto interaktivního prostředí (Hill, Wiley, Nelson, \& Han, 2004); v této souvislosti se ovšem mění některé zavedené postupy, např́klad role učitele a jeho autority ( $M$. Dlouhá, 2011).

Demokratizace informačního prostředí, které se vzdělavatelé často brání, tak může mít velké výhody, pokud se jí ovšem přizpůsobí výukové postupy (Ertmer \& OttenbreitLeftwich, 2010). Obecně je nutné si uvědomit, že OER jsou pouze nástrojem pro zkvalitnění vzdělávání a nikoli vlastním cílem. OER zejména vyvolávají potřebu uplatňování nových přístupů k výuce/učení, tzv. otevřených vzdělávacích postupů (OEP), což může do budoucna značně proměnit vzdělávací systémy jako takové. Vzdělavatelé se tak musí vyrovnat s celkovou změnou přístupů a metod výuky: proměňuje se nejen způsob stanovení vzdělávacích cílů, výběr obsahů, metod, jejich používání v procesu výuky, ale také požadované výsledky učení a způsoby jejich hodnocení (Dlouhá, Adomssent, Barton, \& Fadeeva, 2011) (Dlouhá et al., 2011). Hlavní výzvou je tedy v současné době vytvoření fungujícího systému, který vzdělavatelům umožní nejen dosáhnout na kvalitní OER, ale také podpoří schopnost tyto materiály efektivně využívat ve výuce formou OEP.

\section{Př́klad využití wiki prostředí}

Úkol vytvořit ucelený, vyvážený a informačně bohatý materiál je v oblasti životního prostředí a udržitelného rozvoje poměrně obtížné. Díky mezioborové povaze environmentálních disciplín a celkové neujasněnosti teoretických základů oboru (a navíc stálému rozšiřování o další a další obory s rozdílnými přístupy) není prakticky možné pojmout tuto oblast jednotně - je třeba stále vyjasňovat základní pojmy, metodologická východiska, přístupy, a také vytvářet nové, nadoborové koncepční rámce. Kromě toho se poznání zde velmi rychle 
vyvíjí, přesunují se akcenty dle aktuální potřeby a celkově je nutné včas a pružně reagovat na nové podněty. Do dialogu vstupují nejen různé obory, ale i další společenští hráči, a jejich vklad bývá často klíčový pro hledání možných řešení. Všechny tyto důvody vedly některé $z$ autorů tohoto textu $\mathrm{k}$ volbě interaktivního elektronického prostředí s možností otevřeného editování - od r. 2003 tak vznikala učebnice formou wiki, a to $v$ české, a později též $v$ anglické mutaci, takže její použití mohlo být testováno při různých typech výuky. $V$ tomto prostředí se různé př́stupy mohly potkat a být zohledněny; do tvorby textů byli zapojeni různí aktéři; poznání, které tak vznikalo, bylo tedy více demokratické a zaměřené $\mathrm{k}$ účelům a řešením spíše než příčinám jevů. Samostatná byt́ otevřená wiki poskytla možnost stálého dohledu nad kvalitou vytvářených materiálů. Tyto zkušenosti byly reflektovány "teoreticky" a články o všech těchto projektech byly publikovány u nás i v zahraničí (viz Př́loha 4).

\section{Př́́klad Wikipedie}

Požadavek interaktivního zdroje, který umožňuje zapojení studentů do tvorby odborných textů, naplňuje též Wikipedie - ta má ovšem pro Vš učitele stigma povrchního a neúplného zdroje nabízejícího pouhé zdání vědeckosti. $V$ tomto smyslu je ale také třeba uvažovat, k čemu se takový zdroj používá (Mesgari et al., 2015; Okoli et al. 2012). Wikipedie se podobá skriptům či jiným výukovým materiálům $v$ mnoha ohledech: jde o nekomerční projekt, pokoušející se shrnout a systematizovat znalosti, přičemž zásadou Wikipedie je důsledné citování primárních zdrojů. Rozdíl je $v$ otevřenosti: díky vhodně nastaveným pravidlům se daří na Wikipedii kombinovat práci tisíců přispěvatelů - od elitních kreativních technologických autorů přes nejrůznější podivíny až po mnoho trpělivých "mravenečků", kteří ve Wikipedii dělají systematické kategorizace, jazykové korektury, propojování článků apod. Díky tomu se dnes považuje za historicky největší kompendium světových znalostí (Brown, 2011), jednotlivé texty ale nejsou zaštítěny "autoritou" Vš pedagoga, odborníka na dané téma. Výzkumy ukazují, že na vysoké škole jak většina studentů, tak i pedagogů Wikipedii používá jako zdroj informací (minimálně $75 \%$ ) a část studentů i učitelů také Wikipedii aktivně edituje (cca $8 \%$ ); počet uživatelů na vysoké škole stále stoupá (Knight \& Pryke, 2012). Jak uvádí autoři, kvalitativní výzkum ukázal, že většina studentů používá Wikipedii správně, tj. jako výchozí "odrazový můstek" ke spolehlivým primárním zdrojům, a že oceňují to, jak ve Wikipedii Ize díky kategorizaci a systému hyperlinku" dojít velmi rychle ke správné výchozí stránce, i když na začátku nemusí být úplně jasné, čím se chtějí vlastně zabývat. Pro vysokoškolské studenty by tedy měla Wikipedie sloužit jako informační rozcestník a pomoci jim také při orientaci v ostatních vědních oborech, kterými se ve svém studiu primárně nezabývají (vysvětlení neznámých pojmů), při aktivním zapojení do psaní obsahu pak může sloužit jako velmi dobrý nástroj odborného psaní, často s velmi rychlou zpětnou vazbou na obsah textu, a může být také používána při prípravě a podpoře e-learningových kurzů (Jančařík \& Jančaříková, 2010).

\section{Otázky kvality OER}

Při debatách o využitelností OER je v popředí otázka jejich kvality a to, jak se promítne do kvalitního vzdělávání. Na úrovni Evropské komise se v roce 2014 otázkou kvality zabývala rozsáhlá zpráva State of the Art Review of Quality Issues related to Open Educational Resources (OER). Zpráva ř́ká, že pro zajištění kvality v oblasti OER je zapotřebí nového, uceleného souboru kvalitních nástrojů, které například umožňují mnohem širší škále uživatelů 
zapojení do procesů hodnocení kvality. Dále je třeba propojit vznikající koncept otevřeného vzdělávání s již existujícími sítěmi uživatelů, vzdělavatelů, vydavatelství i formálního vzdělávání (Camilleri et al., 2014).

Kvalita samotných publikovaných materiálů má zásadní vliv na kvalitu výuky/učení; po formální stránce může (anebo nemusí) souviset s použitím copyrightu - to se mj. pokouší osvětlit tento výzkum. Kvalita může být též do značné míry ošetřena vhodnými způsoby certifikace odborné úrovně textů, která spočívá v zajištění jeho nezávislého posouzení (recenze) a vyjádření této skutečnosti vhodnou formou (například uvedením recenzentů či vyjádřením odborné úrovně na základě posudků, viz též (Dlouhý \& Dlouhá, 2012). Všechna opatření pro zajištění kvality na straně samotných OER by $v$ praxi ovšem měla být doplněna o přiměřené školení v užívání a rozlišování důvěryhodnosti (elektronických) zdrojů samotnými studenty.

Protože kvalita OER je jedním z limitů nebo naopak podnětů k širšímu využívání těchto zdrojů, týká se jí jedna z výzkumných otázek kladených v tomto výzkumu, a to z hlediska toho, jak, podle jakých znaků, Ize skutečnou kvalitu materiálů umístěných $v$ online prostředí rozpoznat.

\section{Postup výzkumu}

Výzkum byl proveden týmem autorů, kteří vycházeli ze svých předchozích zkušeností s používáním OER, především snahou o prosazení nových př́stupů a metod ve výuce, která by využívala možností internetu, co se týče rychlého a kvalitního přístupu ke zdrojům v environmentální oblasti, ale též prosazovala nové interaktivní způsoby jejich použití. S tímto záměrem začala vznikat již v r. 2003 Enviwiki jakožto sdílená „znalostní báze" odlišující se od Wikipedie vyšší mírou kontroly (supervize) nad obsahem ze strany učitelů (od r. 2004 funguje její první verze). Bohužel v českém vš prostředí se nikdy nepodařilo na tomto základě vytvořit komunitní projekt (obtižné prosazování myšlenky a získávání většího množství studentů), a relativního úspěchu bylo dosaženo především v mezinárodní výuce podpořené partnerstvím se zahraničními institucemi; zde byla vytvořena VCSEwiki a metoda se používá i v současné době v rámci mezinárodních kurzů European Virtual Seminar koordinovaných Open University of the Netherlands. Výzkumu bezprostředně předcházela studie "Analýza využívání termínu Open Educational Resources na českých vysokých školách v mezinárodním kontextu" (Kapitulčinová et al., v př́pravě).

\section{Předmět zkoumání}

Výběr "objektu" studia OER pro účely tohoto článku byl zúžen na výukové materiály pro VŠ studium, jako např́klad elektronická skripta, knihy nebo učebnice, wiki a jiné učební materiály založené převážně na textu (jiných kategorií se dotkneme pouze okrajově). Vzhledem $\mathrm{k}$ zaměření tohoto výzkumu byla pozornost soustředěna na zdroje pro všeobecné environmentální obory a udržitelný rozvoj, tj. ty, které shrnují v poměrně obecné rovině jejich základní východiska a principy (nikoli tedy určené pro specializovaná studia např́klad technologických postupů či adaptovaných přístupů a metod ekonomických, sociologických apod.). Sledovali jsme materiály, které lze vyhledat na internetu prostým "googlováním", a to takové, které deklarují, že mají sloužit k vysokoškolskému studiu; podle těchto atributů si je pak studenti sami mohou najít a použít jako zdroje pro učení. To bylo též hlavní hledisko našeho výběru: zajímalo nás vše, co si takto pravděpodobně vyhledá na internetu student připravující se ke zkoušce. Některé z takto nalezených materiálů mohou případně sloužit též při psaní závěrečných prací - ty však nebyly primárně ve středu našeho zájmu, protože pro tento účely by mohly být též vyhledávány zdroje dat či další texty podstatně vyšší odborné 
úrovně - např́klad články v odborných časopisech publikované formou Open Access - což by otázky řešené v tomto článku nepřiměřeně komplikovalo. Co se týče "míry otevřenosti", do našeho výběru (jak dále uvidíme) byly zařazeny jak materiály dostupné úplně volně, tak i některé, pro jejichž získání se vyskytly jisté překážky (které ale studenti mohou snadno překonat). To se týká např. materiálů poskytovaných $v$ rámci knihovních služeb, tedy omezenému "publiku" (část z nich ovšem může být dostupná i veřejně), nebo zdrojů dostupných po prostém přihlášení (údajů takto získaných některé komerční servery zřejmě využívají pro distribuci obchodních sdělení).

V rámci interpretace zjištění však kromě pohledu studenta (co si sám najde na internetu) pro nás byl důležitý též pohled učitele (co by mohl doporučit studentům $\mathrm{k}$ př́pravě na zkoušku).

\section{Položení výzkumné otázky}

Cílem této studie je sledovat využitelnost otevřených informačních zdrojů pro vysokoškolské studium a dále zjistit specifické požadavky na ně kladené (obecně zaměřenými) environmentálními obory, což by mohlo zahrnovat například požadavek rychlé aktualizace; zohlednění mezioborové povahy a kontextualizace daného tématu (ukázání problémů v širších souvislostech); důraz na možnost kombinace různých pohledů či přistupů k problematice; propojení s praxí a různými aktéry, kteří ji reprezentují; ve vztahu k výuce pak prípadně jistou míru interaktivity. $\mathrm{S}$ tím těsně souvisejí otázky kvality těchto zdrojů a zvláštních kompetencí (či naopak zlozvyků), které jsou při jejich používání rozvíjeny. Základní výzkumné otázky byly s ohledem na tyto zájmy formulovány takto:

- Jaké typy otevřených elektronických zdrojů se nabízejí vysokoškolským studentům oborů UR a Envi (formou hlavně učebnic, skript a jiných materiálů založených na textu)?

- Co z existujících OER zdrojů by (ne)mohl doporučit VŠ učitel a proč?

- Jaká kritéria kvality Ize v online prostředí sledovat, aby využívání takto publikovaných materiálů mohlo být (ne)doporučeno?

- Naplňují některé z těchto zdrojů specifické požadavky environmentálního vzdělání a vzdělání pro udržitelný rozvoj, které představují nové př́stupy kladoucí důraz na kompetence, mezioborové souvislosti atd.; případně jak?

Jedním z cílů výzkumu je navrhnout a popsat kategorie OER z hlediska jejich vhodnosti pro studium - co vše je $k$ dispozici ( $a$ je pravděpodobně studenty využíváno), jaké studijní návyky si je možno při použivání těchto zdrojů osvojit; kde jsou tedy př́ležitosti nabízené OER co se týče základních cílů vysokoškolského studia, a jak př́padně předcházet nebezpečím. Související otázky kvality tento článek v plné šíri neřeší, jsou zde pouze naznačeny $v$ souvislosti s kompetencemi - žádoucími dovednostmi či nežádoucími zlozvyky rozvíjenými při použití různých typů zdrojů. Důkladné zpracování této problematiky tak čeká na další podobný výzkum.

V průběhu výzkumu můžeme sledovat též další faktory, které se ukáží jako zajímavé či signifikantní - např́klad zda jsou nalezené zdroje specifické pro studijní program nebo univerzální. Výhody a nevýhody př́padného sdílení stejných zdrojů v různých studijních programech však opět položíme jako otázku pro další výzkum (zde hrají významnou roli finanční faktory, které nejsou předmětem našeho zájmu). 


\section{Metoda výzkumu}

Vyhledávání zdrojů bylo provedeno prostým „googlováním" dle klíčových slov, která by použil student hledající podklady pro své studium $v$ obecných (nespecifických) environmentálních vědách (např́klad: „životní prostředí" AND „skripta”, „environmentalistika" AND "vysokoškolské" AND/OR "online" atd.). Takto byly nalezeny zdroje snadno dostupné (na prvních několika stranách vyhledávače), z nichž byly vybrány ty, které typicky odrážely požadavky studenta na hledaný materiál (texty vhodné pro učení se ke zkoušce); cílem nebylo vytvořit úplný seznam či přehled otevřených zdrojů, spíše šlo o to, najít př́iklady různých forem a způsobů publikování v takto specifikovaném žánru.

Z výzkumných otázek byly vytvořeny kategorie, podle kterých pak výzkumníci jednotlivé zdroje slovně popisovali; používali přitom informace získané z webu (většinou bylo zapotřebí prohlédnout jak obecné informace na stránkách, tak také jít na další úrovně informací až k jednotlivým nabízeným zdrojům). Výsledkem byl dokument Excel, kde jednotlivé zdroje byly uspořádány do řádků a kategorie jejich popisu tvořly sloupce; to posléze umožnilo srovnání charakteristik zdrojů $v$ těchto kategoriích navzájem. Popis kategorií provedli společně 3 členové výzkumného týmu, a to tak, že se informace jimi zjištěné navzájem doplňovaly, v některých prípadech po vzájemné diskusi upravovaly. Z přehledu OER zdrojů se tak stala nakonec velmi rozsáhlá tabulka, která pak už nemohla být názorně převedena do textu tohoto článku; jednotlivé její položky byly proto následně transponovány do podoby databáze a jsou nyní dostupné v Enviwiki (kategorie OER).

Přiliš rozsáhlý slovní popis jednotlivých kategorií neposkytl také přehledné informace pro srovnání OER zdrojů; $z$ tohoto důvodu byly následně informace $v$ jednotlivých kategoriích kódovány - to bylo provedeno s ohledem na kritéria kvality OER zdrojů (soubor kritérií zdroje z akademického úhlu pohledu viz Přiloha 4). Kódy pro každou z existujících kategorií byly poté vepsány do stejné excelové tabulky namísto podrobného popisu; ve druhé fázi pak ze souboru takto vytvořených kódů byly vybrány ty, jež se zdály vhodné pro celkové posouzení zdroje z hlediska kvality; ty pak zcela nahradily původní kategorie. Tak byla získána přehledná tabulka, v níž už byl popis zdrojů maximálně zjednodušen a vyjádřen "hodnotami" kódů na škále ANO / NE a 0 - což je hodnota užitá pro různé mezistupně (viz Tabulka 4). Kód pro slovní popis zdroje, který se týká jeho povahy z hlediska environmentálních disciplín, je zde uveden v posledním sloupci.

Kódování bylo provedeno podobným postupem jako popis kategorií - několika členy týmu (zajištění tzv. intercoder reliability). Celkově byl postup založen na několika fázích interpretace, jak doporučují autoři používající tuto metodu kvalitativního výzkumu (Hay, 2000). Současně je možné si představit též třetí fázi, ve které by hodnocení kódů bylo lépe metodicky popsáno, čímž bychom získali indikátory kvality; na tomto základě by pak bylo možné $v$ budoucnu vytvořit komplexní indikátorovou sadu celkově ( $v$ agregované podobě) hodnotící kvalitu zdroje. Tak daleko tento výzkum nedospěl a důkladné kvantitativní hodnocení zdrojů zde provedeno nebylo - hodnoty kódů nejsou ještě kvantitativním výsledkem, ale stále představují kvalitativní popis. Soubor kódů pořád ještě také není komplexní sadou kritérií; přesto může do určité míry vypovídat o celkové vhodnosti zdroje pro vysokoškolskou výuku, jak vidíme $z$ Tabulky 4 . Kódy ovšem vyžadují interpretaci, kterou podáváme jak ve zmíněném posledním sloupci tabulky, tak také $v$ diskusi; vyplývá z ní především relevance zdrojů pro studium a výuku s ohledem na pedagogické cíle, specifické požadavky VUR a jiné sledované faktory.

V souhrnné Tabulce 4 byly OER zdroje pro větší přehlednost rozčleněny do několika skupin navržených s ohledem na míru otevřenosti daného zdroje - to by mělo usnadnit jejich srovnání. Protože $v$ každé skupině uvádíme pouze 3 zdroje jako př́klady, je třeba považovat tento výzkum za explorativní. Pokud však v budoucnosti výzkum dospěje do fáze 
tvorby indikátorů (přičemž jejich soubor by musel být zároveň doplněn o všechna potřebná hlediska), bylo by možné provést srovnání většího počtu OER zdrojů.

\section{Výsledky}

1. Excelová tabulka s popisem OER zdrojů dle faktorů umožňujících srovnání byla transponována na Enviwiki - viz kategorie "OER zdroje".

2. Jejím zjednodušením vznikla Tabulka 4 - popis kódů kvality OER zdrojů, které vznikly zjednodušením jejich popisu $v$ několika předem navržených kategoriích. Zdroje jsou zde členěny podle míry jejich otevřenosti (viz levý sloupec - zdroje otevřené pro čtení, pro úpravy, komerční stránky s materiály pro studium atd.). 


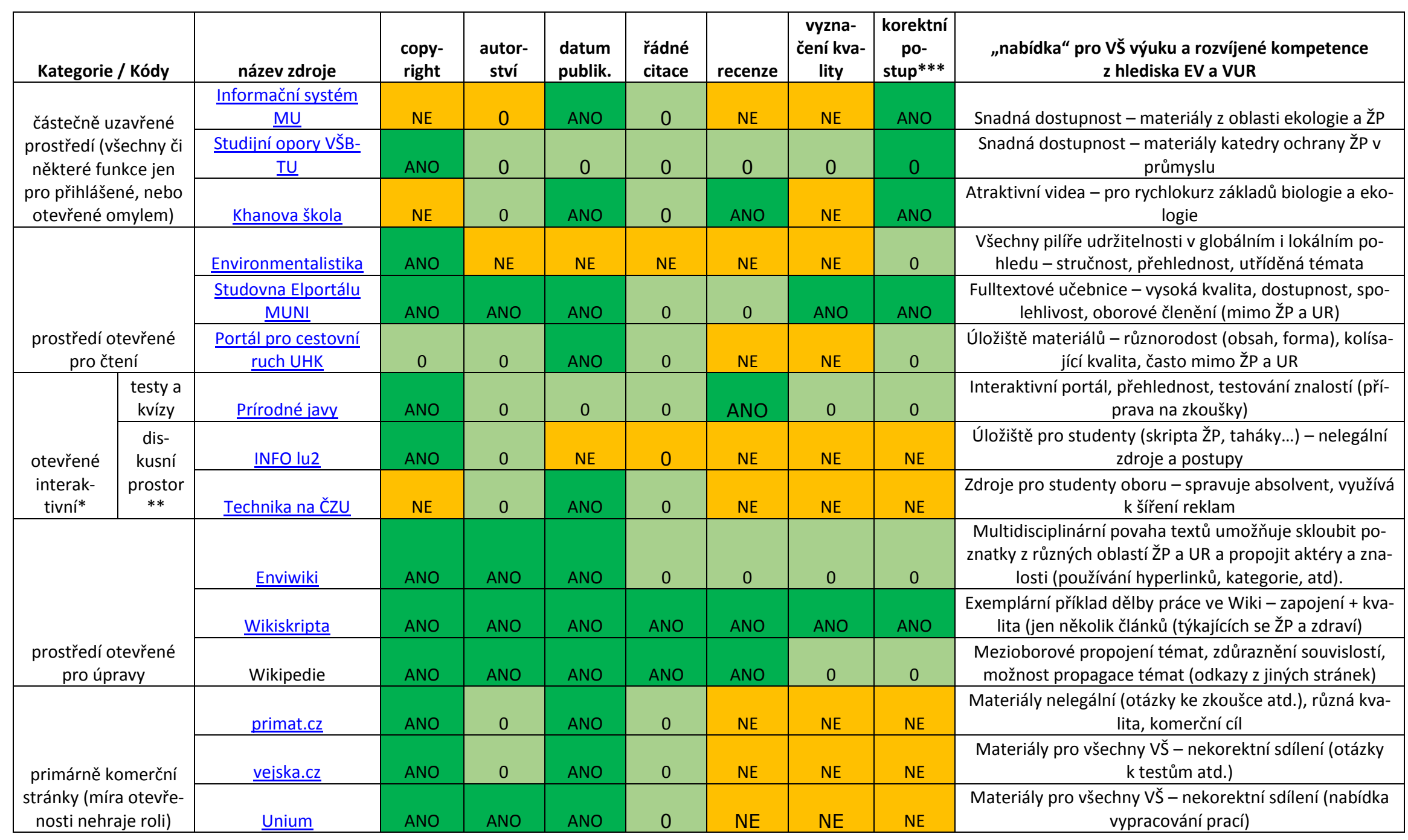

* neumožňující úpravy existujících textů $\quad$ ** možnost přidávat materiály $\quad * * *$ Užití zdroje nevede k plagiátorství; práci s nekvalitními zdroji; nekritickému přístupu,...

Tabulka 4. Výsledek kódování vybraných OER zdrojů podle kritérií kvality. „Hodnoty” kódů (ANO, NE, 0) představují jejich zjednodušený kvalitativní popis: ANO znamená, že dané kritérium bylo víceméně naplněno, NE pak značí opak (většinou dané kritérium naplněno nebylo). „Hodnota" 0 byla užita v př́padech, že nebylo možné z různých důvodů přiřadit zdroji předchozí dvě „hodnoty” (podrobnosti viz diskuze). 


\section{Diskuse}

Prvním a nejvýraznějším zjištěním, které se ukázalo při takto provedeném vyhledávání, bylo velké množství nalezených stránek s obsahem, odporujícím autorskému právu, které nabízejí výukové materiály pochybné kvality, avšak pravděpodobně s úspěchem - na něm je nejspíš postavena komerční strategie jejich tvůrců. Poměrně šokující je v tomto případě fakt, že na první pohled nezákonné materiály na Internetu jsou nabízeny s plným sebevědomím a zřejmým vědomím nepostižitelnosti, často zahrnují informace, které mají původ na samotných vysokých školách (nejen z jejich webových stránek, ale prímo od studentů, absolventů a možná $v$ některých př́padech i od učitelů). Za těchto podmínek není pro studenty pravděpodobně snadné odlišit správné použivání elektronických zdrojů od nesprávného, na které by se $v$ ideálním prípadě měly vztahovat postihy. Pro pohyb $v$ takto nezajištěném prostředí je třeba zvláštního školení, kterého se ovšem na většině vysokých škol nedostává; výsledkem může být všeobecná nedůvěra $v$ jakékoli online materiály kombinovaná s jejich "tajným" používáním.

Co se týče intepretace jednotlivých kódů a jejich souvislostí s možnostmi posuzování kvality zdroje, Ize usuzovat, že:

- Copyright nelze $v$ žádném prípadě pokládat za kritérium kvality - tuto licenci mají především všechny nelegální stránky. $V$ námi popsaných př́padech může použití copyrightu pro celý web souviset se snahou prokázat (neexistující) kvalitu nebo odradit od podrobného zkoumání práv původních autorů jednotlivých materiálů.

- Copyright na výukových materiálech publikovaných důvěryhodnou institucí (např. UHK) pak klade opačné otázky: jak Ize jejich díla vůbec použít, například formou sdílení s dalšími studenty?

- Licence CC se zřejmě u nás těší stejné nedůvěře, jako její hlavní nositel - Wikipedie: není totiž použita ani u zdrojů, které vznikly z veřejných prostředků. Naopak tam, kde je používána standardně (u všech wiki zdrojů, z nichž zde uvádíme jen ty, jež jsou relevantní pro zvolené obory), svědčí o vytváření zdroje přímo pro zvláštní způsoby jeho používání (flexibilní texty, které Ize přizpůsobit různým možným způsobům použití).

- Uvedení autorství, datum vytvoření/publikování zdroje a práce s primární literaturou jsou běžné znaky pečlivé práce $s$ textem. Přesto tyto atributy někdy chybí i materiálům, které aspirují na kvalitní zdroje - svědčí o jistém problému při jejich tvorbě (rozdíl mezi materiály MUNI, která má vypracovanou strategii, a výsledkem projektu UHK, který velmi pravděpodobně není systémovým dlouhodobým řešením, spíše je nastaven na produkci „výsledků" v pojetí OPVK).

- Zvláštní pozornost je třeba věnovat kódu Recenze. Texty, které prošly touto fází, mají svým způsobem zajištěnou kvalitu; zde se nejlépe projeví rozdíly mezi zkoumanými zdroji. $V$ př́padě materiálů, které nebyly zveřejněny pod svobodnou licencí, je tento atribut vyznačen jednoznačně pouze někde (např. MUNI). Recenze jsou ale součástí kvalitního publikačního procesu učebních textů na bázi wiki: pro Wikiskripta je zajištúuje tým pedagogů $s$ určenými rolemi $v$ rámci redakčního týmu. To je též hlavní rozdíl mezi využitím tohoto média pro výuku, a jiného, který mírí na všeobecnou osvětu (což má za cíl Wikipedie). 
Co se týče vhodnosti OER zdrojů pro vysokoškolské studium, můžeme usuzovat, že většinou jejich výhody spočívají ve snadné dostupnosti informací, někdy též zpřehlednění tématu - to ale na druhé straně může vést $\mathrm{k}$ jistým zlozvykům při studiu (využití především nejsnadněji dostupných materiálů a nedostatek cviku při cíleném vyhledávání vhodných textů např. $v$ rámci knihovních služeb). Studium z námi nalezených zdrojů nevyžaduje žádné zvláštní schopnosti (nebo jen základní ICT dovednosti); specifické kompetence jsou ale rozvíjeny při tvorbě takto publikovaných textů, jež může být též součástí výuky (v různém wiki prostředí).

S ohledem na vhodnost pro environmentální obory, Ize se domýšlet, že požadavek chápání témat $v$ souvislostech naplňují hypertexty, kde pomocí odkazů je možno hledat a přemýšlet nad oborově různorodými oblastmi. Fungující výukový materiál takto založený existuje $v$ př́buzné oblasti - medicíně -, která podobně jako vědy o životním prostředí prosazuje holistický pohled (na člověka) na straně jedné, a kombinaci různých oborů pro praktické zásahy do jeho organismu na straně druhé.

\section{Metodické otázky}

Při kódování popisu jednotlivých kategorií z hlediska kvality daného OER bylo potřeba určit základní znaky a přitom zachovat přehlednou strukturu; proto byly zvoleny pouze tři stupně popisu: $A N O, N E, 0$, kde 0 vyjadřuje mezistupeň, např́ílad pokud se jev vyskytuje pouze $v$ některých prípadech (členění na další stupně by dokument znepřehlednilo). Kódování některých zdrojů bylo ovšem problematické a zasluhuje proto vysvětlení. U zdroje Studijní opory VŠB- TU a Informační systém MU (studijní materiály) nešlo - vzhledem k částečně uzavřenému prostředí - zjistit všechny parametry, byly proto kódovány jako 0 . Recenzní řizení u většiny zkoumaných zdrojů neprobíhá. $V$ prípadě, že proběhlo pouze u určitých materiálů, bylo kódováno jako 0 . Některé zdroje nicméně zmiňují funkci správce (např. vejska.cz), ten však pravděpodobně nekontroluje kvalitu ale pouze technickou stránku (není zmíněno ani jméno správce, ani posuzování z hlediska kvality), proto je kódováno jako NE. Odlišná situace je u Khanovy školy či portálu Prírodné javy, kde jsou vyjmenováni a popsáni správci (kdo za projektem stojí), kteří tedy plní určitým způsobem roli recenzentů. U Wikipedie byl ve sloupci "recenze" vybrán kód ANO vzhledem k tomu, že většina článků je editována a prochází v nějaké formě recenzním řízením; existují zde ale i některé články, které editovány nebyly (to je možno zjistit $v$ historii). Většina zkoumaných zdrojů také obsahuje materiály, které mají různou kvalitu citací (sloupec „ř́dné citace"), v tomto prípadě záleží spíše na konkrétním materiálu (jeho autorovi), než na zdroji jako celku, jsou proto často kódovány jako 0 . $V$ prípadě Wikipedie je vyznačeno řádné citování, vzhledem $\mathrm{k}$ tomu, že je často prítomno a jeho dodržování je jednou ze zásad Wikipedie, $v$ praxi se ovšem také můžeme setkat $\mathrm{s}$ jeho nedodržováním (což je $v$ prrípadě cs.wikipedia zapříčiněno zejména nízkým počtem členů české komunity).

Je zřejmé, že výhody jednotlivých OER (či jejich skupin) se mohou lišit v pohledu studenta a učitele - podobně jako mohou být $v$ těchto perspektivách viděny odlišně samotné cíle VŠ výuky. Aby mohlo dojít $\mathrm{k}$ jejich sblížení (především tam, kde cílem studia je často snadnost, na rozdíl od poctivé výuky, která má klást nejvyšší možné nároky), musí být prohloubena výuka kritického posuzování kvality zdrojů a rozšířena o přehled online žánrů. Pokud by dále byl ve výuce/učení kladen dưraz na kompetence, elektronické prostředí poskytuje velké množství př́ležitostí pěstovat jejich širokou škálu, včetně těch, které jsou potřebné právě v praxi udržitelného rozvoje.

„Vedlejším produktem" zde nastíněné snahy o co nejpřesnější a nejúspornější popis OER zdrojů je soubor kritérií jejich kvality (kódy v Tabulce 4). Tento soubor si nečiní nárok 
na úplnost, nicméně je použitelný v praxi: Ize podle nich zlepšovat kvalitu online publikovaných materiálů (napríklad pečlivým uvedením všech atributů jako je autorství, datum vydání, copyright; a zajištěním publikačních postupů jako jsou napríklad recenze atd.).

\section{Diskuse dopadu OER na pedagogické přístupy}

Jak již bylo zmíněno v úvodu, digitální a informační technologie začínají celosvětově měnit také podobu vzdělávání a celkové vzdělávací paradigma. Oficiální dokumenty (Zpráva COL \& UNESCO, 2011) uvádí, že díky snadnosti, se kterou mohou být digitální zdroje sdíleny a šiřeny přes internet, mohou OER do budoucna značně ovlivnit transformaci vzdělávacího systému jako takového (Kanwar et al., 2011). Hlavní roli v tomto procesu hrají vysoké školy, a právě zde by tak měly vznikat a být diskutovány nejen samotné OER zdroje, ale též inovativní způsoby jejich použití ve výuce a nové pedagogické přistupy, které mohou mít pozitivní vliv např́klad na:

- informační gramotnost, a to právě s důrazem na obory ŽP a UR. Texty publikované na internetu totiž nelze pouze číst jako klasické knihy, orientace $v$ hypertextu je založena na schopnosti volit vlastní cestu informačním prostředím pomocí hyperlinků. Tento typ inovace má značné uplatnění právě ve VUR (mezioborové př́stupy), a to proto, že vyžaduje aktivní přístup ke studiu, a samostatnost při hledání zdrojů pro potřeby učení a výzkumu.

- způsob spolupráce: zapojením různých aktérů pomocí ICT mohou vznikat „komunity zájmu", které propojují žáky, studenty i učitele a př́padné další aktéry, což je vysoce relevantní pro VUR z hlediska uplatňování těchto principů v následné profesní praxi UR (vznik "komunity praxe").

- rozvoj důležitých kompetencí, např́klad schopnosti reflexe procesů učení a na tom založené sebereflexe. Je nezbytné, aby si studenti vlastní procesy učení sami (dle svých schopností) ř́dili, uměli si stanovit priority, organizovat svůj čas a dovedli rozpoznat a ocenit kvalitu zdrojů, které využívají, což celkově prospěje jejich práci. Se schopností ř́dit si vlastní postup učení souvisí umění si samostatně položit vhodné otázky, na které studovaný text potom odpovídá - dle konkrétního požadavku či zájmu. Bez řádné (sebe)reflexe a následného řizení mohou být takto nastavené procesy učení př́liš složité.

\section{Závěry}

V prostředí internetu existuje velká různorodost a kvalita zdrojů. Pro jejich využívání jsou navržena systémová řešení (Masarykova Univerzita, Wikiskripta), setkáme se s iniciativami produkujícími kvalitní materiály, o které následně dobře pečují (Ekospace). Na druhé straně se pod hlavičkou OER setkáváme s online úložišti nekvalitního materiálu, který byl nakupen např́iklad v rámci projektů financovaných z českých i evropských prostředků; slouží pravděpodobně především $\mathrm{k}$ naplnění cílů těchto projektů, hůře už ke skutečnému svému účelu - vzdělávání vysokoškolských studentů. Pokud se tak děje, studenti získávají pochybné informace spolu se studijními zlozvyky: neschopností rozlišit kvalitní informační zdroje od druhořadých, což potom vede k pasivnímu memorování nepochopitelných (protože nesmysIných a nesouvisejících) pouček. Na vině OER a četných nekvalitních zdrojů takto vytvořených se nesou (pravděpodobně úspěšné) snahy o zneužití - četné komerční weby nabízející podobné "výukové materiály", ale především produkty a služby včetně vytvoření bakalářských a diplomových prací na objednávku. Nicméně nekvalitu v OER Ize s určitou 
zkušeností odhalit, posoudit a následně eliminovat - alespoň co se týče využívání nekvalitních zdrojů. Prvním krokem k systémovému hodnocení kvality online zdrojů je i zde představený výzkum.

V článku byl podán ne zcela vyčerpávající přehled o zdrojích OER pro environmentální a UR studia v ČR, byly navrženy skupiny zdrojů dle míry jejich otevřenosti. Relevance existujících OER pro VŠ studium byla diskutována obecně, a též specificky pro mezioborové studium oborů environmentálních a UR. Byla navržena kritéria kvality OER materiálů, která byla předběžně vyhodnocena pro různé typy OER zdrojů; dále byly naznačeny (ne)výhody jednotlivých OER s ohledem na obecné cíle VŠ výuky, a zvláště pak z hlediska proměny paradigmatu $v$ environmentálním vzdělávání a ve vzdělávání pro udržitelný rozvoj na VŠ úrovni. Ze závěrů vyplynulo, že pro odstranění nevýhod OER (velmi podstatných a limitujících, avšak ne všude se projevujících) je třeba akutně řešit právě otázky jejich kvality. Tak se mohou naplno projevit výhody OER, které zvláště v oblasti UR a environmentální mají velký potenciál pro zlepšení vysokoškolské výuky: rozšiřují ji o nové přístupy a možnosti práce se zdroji i vzájemné spolupráce při tvorbě výukových textů. Širší užívání OER se ale dosud těžko prosazuje právě proto, že vzhledem $\mathrm{k}$ různorodé kvalitě zdrojů panuje $\mathrm{v}$ této oblasti „oprávněná" nedůvěra.

Pokud bychom měli zrekapitulovat důvody proč i na VŠ úrovni nabízet informace "otevřenou" formou, musíme konstatovat, že (jak víme ze své zkušenosti) je studenti stejně používají, a to bez náležitého vedení často $s$ přehnanou důvěrou. Otevřenost se ale musí prosazovat jako nová filosofie a zakládat nový pedagogický př́stup; otevřená pedagogika může totiž snadno absorbovat inovace a poměrně pružně si vybírat z moderních vzdělávacích metod (např. princip převráceného učení, učení se navzájem, či předávání zkušeností z řešení problémů) podporujících důležité dovednosti a gramotnosti.

\section{Podpora a poděkování}

Tento článek vznikl v rámci projektu "Využití regionálních př́padových studií udržitelného rozvoje ve vysokoškolské výuce a pro tvorbu tzv. Open Educational Resources" (TD020400) financovaného Technologickou agenturou České republiky, jíž patři poděkování. Děkujeme také studentce Kateřině Spustové za pomoc s vyhledáváním dat pro zpracování $\checkmark$ rámci provedené analýzy.

\section{Literatura}

- Atkins, D. E., Brown, J. S.,Hammond, A. L., (2007). A review of the open educational resources (OER) movement: Achievements, challenges, and new opportunities. Creative Common. : Creative common. Retrieved from http://www. hewlett.org/uploads/files/ReviewoftheOERMovement.pdf

- Bissell, A. (2009). Permission granted: open licensing for educational resources. Open Learning: The J. of Open \& Distance Learning, 24(1), 97-106. Retrieved from http://www.tandfonline.com/doi/abs/10.1080/02680510802627886 http://dx.doi.org/10.1080/02680510802627886

- Bissell, A., \& Boyle, J. (2007). Towards a Global Learning Commons: ccLearn. Educational Technology, 47(6), 5-9. 
- Bozkurt, A., Akgun-Ozbek, E., Yilmazel, S., Erdogdu, E., Ucar, H., Guler, E., ... Goksel-Canbek, N., (2015). Trends in distance education research: A content analysis of journals 2009-2013. The International Review of Research in Open and Distributed Learning, 16(1), 1.

- Brand, R., \& Fischer, J. (2013). Overcoming the technophilia/technophobia split in environmental discourse. Environmental Politics, 22(2), 235-254. Retrieved from http://www.tandfonline.com/doi/abs/10.1080/09644016.2012.730264 http://dx.doi.org/10.1080/09644016.2012.730264

- Brown, A. (2011). A Brief History of Encyclopaedias: From Pliny to Wikipedia.. Hesperus Press: Hesperus Press.

- Brown, J. (2008) Creating a culture of learning. In T. Iiyoshi \& M. S. V. Kumar (Eds.), Opening Up Education: The Collective Advancement of Education Through Open Technology, Open Content, and Open Knowledge; Opening up education. In T. Iiyoshi \& M. S. V. Kumar (Ed.), Opening Up Education: The Collective Advancement of Education Through Open Technology, Open Content, and Open Knowledge; Opening up education, Edited by: MIT Press.

- Caldwell, L. (1983). Environmental Studies: Discipline or Metadiscipline. Environ. Prof.; (United States), 5(3), 3. Retrieved from http://www.osti.gov/scitech/bib$\underline{\text { lio/7121934 }}$

- Camilleri, A. F., Ehlers, U. D., \& Pawlowski, J. (2014). State of the art review of quality issues related to open educational resources (OER. Retrieved from http://www.pedocs.de/volltexte/2014/9101/pdf/European Commission_2014_OER.pdf

- Caswell, T., Henson, S., Jensen, M., Wiley, D., (2008). Open Content and Open Educational Resources: Enabling universal education. The International Review of Research in Open and Distance Learning, 9(1), Retrieved from http://www.irrodl.org/index.php/irrodl/article/view/469

- Col. \& UNESCO, (2011). Guidelines for Open Educational Resources (OER) in Higher Education. Commonwealth of Learning \& UNESCO. : UNESCO.

- Creative Commons (2015a). . Creative Commons Česká republika | Oficiální stránky veřejných licencí Creative Commons pro Českou republiku, Retrieved from http://www.creativecommons.cz/

- Creative Commons (2015b). What is OER? - Creative Commons. . Retrieved from https://wiki.creativecommons.org/wiki/What is OER\%3F

- Dlouhá, J., Adomssent, M., Barton, A., \& Fadeeva, Z. (2011). Learning for sustainable development in regional networks. Journal of Cleaner Production, 19(9-10), 1144-1145. Retrieved from http://linkinghub.elsevier.com/retrieve/pii/S0959652611000436 http://dx.doi.org/10.1016/j.jclepro.2011.02.002

- Dlouhá, J., \& Burandt, S. (2015). Design and evaluation of learning processes in an international sustainability oriented study programme. In search of a new educational quality and assessment method. Journal of Cleaner Production, 106, 247258. Retrieved from http://linkinghub.elsevier.com/retrieve/pii/S095965261401035X http://dx.doi.org/10.1016/j.jclepro.2014.09.096 
- Dlouhá, J., Dlouhý, J., \& Barton, A. G. (2010). Vzdělávání metodou e-learningu podporující regionální spolupráci a vytváření evropského vzdělávacího prostoru $v$ interdisciplinární oblasti životního prostředí. Envigogika, 5(3), 10-14712. Retrieved from http://www.envigogika.cuni.cz/index.php/Envigogika/article/view/56 http://dx.doi.org/10.14712/18023061.56

- Dlouhá, J., \& kol., . Metodika tvorby textů $v$ otevřeném internetovém prostoru Enviwiki (schváleno MŽP ČR 31.1.2012, pod č.j. 5782/ENV/12; 154/320/12). . Retrieved from http://www.enviwiki.cz/wiki/Meto-

dika_tvorby_text $\%$ C5\%AF_v_otev\%C5\%99en\%C3\%A9m_internetov\%C3\%A9m_prostoru

- Dlouhá, M. (2011). Autorita ve virtuálním vzdělávání. Envigogika, 6(2), 10-14712. Retrieved from http://www.envigogika.cuni.cz/index.php/Envigogika/article/view/60 http://dx.doi.org/10.14712/18023061.60

- Dlouhý, J., Dlouhá, J., (2012). Metodika využití Wiki (Wiki - metodika - schváleno MŽP ČR 31.1.2012 pod Č.j. 5782/ENV/12; 154/320/12). : 5782/ENV/12; 154/320/12). Retrieved from http://www.enviwiki.cz/wiki/Wiki - metodika

- Ertmer, P. A., \& Ottenbreit-Leftwich, A. T. (2010). Teacher Technology Change. Journal of Research on Technology in Education, 42(3), 255-284. Retrieved from http://www.tandfonline.com/doi/abs/10.1080/15391523.2010.10782551 http://dx.doi.org/10.1080/15391523.2010.10782551

- Hay, I. (2000). Qualitative research methods in human geography.,

- Hemetsberger, A. (2006). Learning and Knowledge-building in Open-source Communities: A Social-experiential Approach. Management Learning, 37(2), 187214. Retrieved from http://mlq.sagepub.com/cgi/doi/10.1177/1350507606063442 http://dx.doi.org/10.1177/1350507606063442

- Hewlett Foundation (2015). Open Educational Resources. . Retrieved from http://www.hewlett.org/programs/education/open-educational-resources

- High Level Group on the Modernisation of Higher Education (2014). Report to the European Commission on New modes of learning and teaching in higher education. European Commission, Luxembourg: Publications Office ofthe European Union.

- Hill, J. R., Wiley, D., Nelson, L. M., \& Han, S. (2004). Exploring research on Internet-based learning: From infrastructure to interactions. Handbook of research on educational communications and technology, 2, 433-460. Retrieved from http://studyonthebeach.com/csusb/classes/archive/spring2011/etec 674 spring 2011/readings/16.pdf

- Chen, Y., \& Peng, S. S. (2008). University Students' Internet Use and Its Relationships with Academic Performance, Interpersonal Relationships, Psychosocial Adjustment, and Self-Evaluation. CyberPsychology \& Behavior, 11(4), 467-469. Retrieved from http://www.liebertonline.com/doi/abs/10.1089/cpb.2007.0128 pmid:18721095 http://dx.doi.org/10.1089/cpb.2007.0128

- Chou, C., Condron, L., \& Belland, J. C. (2005). A Review of the Research on Internet Addiction. Educ Psychol Rev, 17(4), 363-388. Retrieved from http://link.springer.com/10.1007/s10648-005-8138-1 http://dx.doi.org/10.1007/s10648-005$\underline{8138-1}$ 
- Jančařík, A., \& Jančaříková, K. (2010) Wiki tools in the preparation and support of e-learning courses. In Proceedings of the 8th European Conference on e-Learning (s. 276). Academic Conferences Limited. : In Proceedings of the 8th European Conference on e-Learning (s. 276). Academic Conferences Limited.

- Kanwar, A., Uvalić-Trumbić, S., \& Butcher, N. (2011). A basic guide to open educational resources (OER). Vancouver: Commonwealth of Learning. Paris: UNESCO.

- Kapitulčinová, D., Spustová, K., Nemcová, M., \& Petiška, E. (2016). Analýza využívání termínu Open Educational Resources na českých vysokých školách v mezinárodním kontextu - článek $v$ prípravě. Aula,

- Kauppinen, I. (2014). Different Meanings of 'Knowledge as Commodity' in the Context of Higher Education. Critical Sociology, 40(3), 393-409. Retrieved from http://crs.sagepub.com/cgi/doi/10.1177/0896920512471218 http://dx.doi.org/10.1177/0896920512471218

- Knight, C., \& Pryke, S. (2012). Wikipedia and the University, a case study. Teaching in Higher Education, 17(6), 649-659. Retrieved from http://www.tandfonline.com/doi/abs/10.1080/13562517.2012.666734 http://dx.doi.org/10.1080/13562517.2012.666734

- Kolektiv autorů (2009). Texty o proměně vztahů lidí k prírodě, environmentální výchově a udržitelnosti. Praha: Zelený kruh. Retrieved from http://www.zelenykruh.cz/wp-content/uploads/2015/01/300409 clovek-priroda fin.pdf

- Kolektiv autoru (2012). What is the Paris OER Declaration? | United Nations Educational, Scientific and Cultural Organization. . Retrieved from http://www.unesco.org/new/en/communication-and-information/access-to-knowledge/open-educational-resources/what-is-the-paris-oer-declaration/

- Mesgari, M., Okoli, C., Mehdi, M., Nielsen, A. (Finn), , \& Lanamäki, A. (2015). "The sum of all human knowledge": A systematic review of scholarly research on the content of Wikipedia. J Assn Inf Sci Tec, 66(2), 219-245. Retrieved from http://doi.wiley.com/10.1002/asi.23172 http://dx.doi.org/10.1002/asi.23172

- Nocar, D. (2004). E-learning v distančním vzdělávání. Olomouc: Univerzita Palackého. Retrieved from http://servere.csvs.cz/konference/NCDiV2004_sbornik/Nocar-231-237.pdf

- OECD, (2007). Giving Knowledge for Free, The Emergence of Open Educational Resources. .

- Lanamaki, A., Mehdi, M., Mesgari, M., Nielsen, F., \&.a,", , \& Lanamaki, A. (2012). The People's Encyclopedia Under the Gaze of the Sages: A Systematic Review of. Scholarly Research on Wikipedia. SSRN Electronic Journal., Retrieved from http://www.ssrn.com/abstract=2021326 http://dx.doi.org/10.2139/ssrn.2021326

- Prensky, M. (2009). H. sapiens digital: From digital immigrants and digital natives to digital wisdom. Innovate: Journal of online education, 5(3), Retrieved from http://nsuworks.nova.edu/cgi/viewcontent.cgi?article $=1020 \&$ context $=$ innovate 
- Richter, T., \& McPherson, M. (2012). Open educational resources: education for the world. Distance Education, 33(2), 201-219. Retrieved from http://www.tandfonline.com/doi/abs/10.1080/01587919.2012.692068 http://dx.doi.org/10.1080/01587919.2012.692068

- Sachs, J. D. (2012). From Millennium Development Goals to Sustainable Development Goals. The Lancet, 379(9832), 2206-2211. Retrieved from http://linkinghub.elsevier.com/retrieve/pii/S0140673612606850 http://dx.doi.org/10.1016/S0140-6736(12)60685-0

- Strejčková, E. (1998). Děti pro pětihory. Praha: ZS Toulcův dvůr.

- Strejčková,E., (2005). Děti, aby byly a žily. : Ministerstvo životního prostředí ČR. Retrieved from http://www.ekodomov.cz/fileadmin/4 Ekocentrum Sarynka/Detsky_klub/Publikace/deti_aby_byly_a_zily.pdf

- Trojan, J., \& Trávníček, J. (2014) Nástroje umožňující kolaborativní práci v LMS Moodle a jejich adaptace $v$ univerzitním prostředí. In Konference moodleMoot. cz. : In Konference moodleMoot. cz. Retrieved from http://2014.moodlemoot.cz/pluginfile.php/31/mod_data/content/96/TroTra_MoodleMoot_final.docx

- Wals, A., Brody, M., Dillon, J., \& Stevenson, R. B. (2015). Propojení prírodovědného a environmentálního vzdělávání. Envigogika, 10(2), 10-14712. Retrieved from http://www.envigogika.cuni.cz/index.php/Envigogika/article/view/458 http://dx.doi.org/10.14712/18023061.458

- Willems, J., \& Bossu, C. (2012). Equity considerations for open educational resources in the glocalization of education. Distance Education, 33(2), 185-199. Retrieved from http://www.tandfonline.com/doi/abs/10.1080/01587919.2012.692051 http://dx.doi.org/10.1080/01587919.2012.692051

- Zahradník, M., \& Pachmanová, L. (2009). Příklad využití wiki-prostředí v environmentálním vzdělávání na vysoké škole: hodnocení kurzu Organizace a řízení ochrany životního prostředí. Envigogika, 4(3), 10-14712. Retrieved from http://www.envigogika.cuni.cz/index.php/Envigogika/article/view/46 http://dx.doi.org/10.14712/18023061.46

- Ziegler, C. Richard, , Webb, J. Angus, , Norton, S. B., Pullin, A. S., \& Melcher, A. H. (2015). Digital repository of associations between environmental variables: A new resource to facilitate knowledge synthesis. Ecological Indicators, 53, 61-69. Retrieved from http://linkinghub.elsevier.com/retrieve/pii/S1470160X15000047 http://dx.doi.org/10.1016/j.ecolind.2015.01.003 


\section{Přílohy}

\section{PŘÍLOHA 1 - Souvislost mezi OER a Cíli udržitelného rozvoje}

Cíle udržitelného rozvoje (Sustainable Development Goals, SDGs) byly v září 2015 přijaty na úrovni Organizace spojených národů jako celosvětová agenda na dalších patnáct let. SDGs jsou novým mezinárodním konceptem navazujícím na Rozvojové cíle tisíciletí (angl. Millenium Development Goals, MDGs). MDGs vznikly jako rozvojová agenda OSN v roce 2000 s platností do roku 2015. V současnosti připravované SDGs tedy mají volně navázat na MDGs a nastavit celosvětové směřování společnosti na dalších patnáct let (Sachs, 2012). Celý proces přípravy SDGs trval několik let a vyvrcholí přijetím této rozvojové agendy na konferenci OSN v září 2015. Jednotlivé navrhované cíle a dílčí podcíle jsou již v současnosti schválené (jsou dostupné na sustainabledevelopment.un.org ).

Pro zhodnocení konceptů OER a OEP v kontextu SDGs jsme se v textu schválených 17 cílů (Goals) a jejich 169 podcílů (Targets) zaměřili na tři základní principy konceptů OER: otevřenost vzdělávání, přístup k informacím a využívání ICT.

Vzdělávání má v rámci navrhovaných SDGs velmi významnou roli, je mu tedy věnován celý jeden cíl, tj. „Cíl 4: Zajistit inkluzivní a spravedlivé kvalitní vzdělání a podporovat př́ležitosti k celoživotnímu vzdělávání pro všechny". Inkluzivnost a spravedlnost v přístupu ke vzdělávání je právě jedním z motivujících faktorů komunity prosazující širší využívání OER a OEP a otevřeného vzdělávání jako takového (COL \& UNESCO, 2011). Vzdělávání (Education) je v navrženém dokumentu zmíněno celkem třináctkrát ve čtyřech různých cílech.

Volný přístup k informacím je obsažen ve dvou navržených cílech: „Cíl 12: Zajistit udržitelné vzorce výroby a spotřeby” a „Cíl 16: Podporovat mírumilovné a inkluzivní společnosti pro udržitelný rozvoj, poskytnout př́stup ke spravedlnosti pro všechny a vybudovat efektivní, odpovědné a inkluzivní instituce na všech úrovních". V těchto cílech je například explicitně zmíněn „volný přístup k informacím pro život v souladu s přírodou”.

Co se týče využívání informačních a komunikačních technologií (ICT), je v dokumentu kladen velký důraz na jejich budoucí širší a efektivnější využívání. ICT je zde zmíněno celkem čtyřikrát ve čtyřech různých cílech: „Cíl 4: Zajistit inkluzivní a spravedlivé kvalitní vzdělání a podporovat příležitosti k celoživotnímu vzdělávání pro všechny", "Cíl 5: Dosáhnout genderové rovnosti a podpořit všechny ženy a dívky", "Cíl 9: Vybudovat resilientní infrastrukturu, podpořit inkluzivní a udržitelnou industrializaci a rozvíjet inovace", "Cíl 17: Posílit prostředky k implementaci a revitalizovat globální partnerství pro udržitelný rozvoj". Ve všech těchto cílech je ICT prezentována jako „umožňující technologie” (enabling technology), která je využitelná v mnoha různých směrech. Aplikace ICT pro otevřené vzdělávání je tedy jednou z možností využití.

Z této analýzy navrhované celosvětové agendy OSN je možné udělat závěr, že principy otevřeného vzdělávání podporují koncept žádoucího vývoje společnosti do roku 2030. To je v souladu se zjištěním studie Mezinárodní telekomunikační unie (ITU), jež se zabývá korelacemi mezi jednotlivými Cíli udržitelného rozvoje a informačními a komunikačními technologiemi (podrobnosti zde). 


\section{PŘÍLOHA 2 - Základní typy OER}

OER jsou zde rozděleny do několika typů podle obsahu, nástrojů a implementačních zdrojů vhodných pro efektivní vytváření a šíření OER mezi další uživatele. Nejucelenější a nejaktuálnější takové tř́ídění OER je $v$ současnosti obsaženo ve zprávě Evropské komise $\mathrm{k}$ OER, která ve své klasifikaci rozlišuje tři základní typy OER viz Tabulka č. 2.

Tabulka 2. Základní typy OER a př́klady z praxe (modifikováno dle (Camilleri et al., 2014). Zvýrazněny jsou OER, jimiž se zabýváme.

\begin{tabular}{|c|c|}
\hline $\begin{array}{l}\text { Typy otevřených vzdělávacích } \\
\text { zdrojů }\end{array}$ & Příklady z praxe \\
\hline \multicolumn{2}{|l|}{ Nástroje } \\
\hline - systém managementu obsahu/zdrojů & eduCommons, EPrints \\
\hline - sociální software & MediaWiki, BuddyPress \\
\hline $\begin{array}{l}\text { - nástroje pro tvorbu (development to- } \\
\text { ols) }\end{array}$ & OpenStax (dřive Connexions) \\
\hline - systém managementu výuky & Moodle, Sakai \\
\hline \multicolumn{2}{|l|}{ Obsah } \\
\hline - vzdělávací objekt (learning object) & Merlot, OpenStax (dřive Connexions) \\
\hline - ucelené materiály kurzů (courseware) & MOOC, OpenCourseWare \\
\hline - kolekce referencí & $\begin{array}{l}\text { Open Archives, Databáze časopisů (Google } \\
\text { Scholar apod.) }\end{array}$ \\
\hline \multicolumn{2}{|l|}{ Implementační zdroje } \\
\hline - licenční nástroje & Creative Commons, GNU licence \\
\hline - příklady dobré praxe (best practices) & CMU Open Learning \\
\hline $\begin{array}{l}\text { - standardy pro společné fungování (in- } \\
\text { teroperability standards) }\end{array}$ & $\begin{array}{l}\text { Open IMS Core, Sharable Content Object Re- } \\
\text { ference Model (SCORM) }\end{array}$ \\
\hline
\end{tabular}




\section{PŘÍLOHA 3 - Přehled licencí Creative Commons (CC)}

Klasické majetkové autorské právo k autorskému dílu je dle našich zákonů nepřevoditelné a trvá do doby 70 let po smrti autora. Pokud takovéto dílo je pouze pod takovouto ochranou, je nutné prakticky pro jakékoliv použití libovolného díla získat souhlas autora, resp. jeho dědiců (s určitými výjimkami v případě soukromého použití, apod.). Toto právo však může být omezeno autorskou licencí, kterou autor dílu přiřadí a která upraví možnost dílo dále vymezeným způsobem používat bez explicitního souhlasu autora. V praxi se nejčastěji užívají licence Creative Commons (CC), které mají celkem 6 variant (viz Tabulka 3). Ty vymezují práva a povinnosti nabyvatele následujícím způsobem:

Tabulka 3. Přehled licencí Creative Commons (CC)

\begin{tabular}{|c|c|}
\hline \multicolumn{2}{|c|}{ PIně svobodné licence umožňující všechny aktivity vyžadované pro OER } \\
\hline BY & Uved'te původ \\
\hline BY-SA & Uvedte původ - Zachovejte licenci \\
\hline \multicolumn{2}{|c|}{$\begin{array}{l}\text { Licence svobodné pro nekomerční sféru (tedy i pro vysoké školy) - tedy též vy- } \\
\text { užitelné většinou pro OER }\end{array}$} \\
\hline $\mathrm{BY}-\mathrm{NC}$ & Uved'te původ - Nevyužívejte komerčně \\
\hline \multicolumn{2}{|c|}{ BY - NC - SA Uved'te původ - Nevyužívejte komerčně - Zachovejte licenci } \\
\hline \multicolumn{2}{|c|}{$\begin{array}{l}\text { Licence, které neumožňují plně svobodné využití (dovolují publikování díla, ale } \\
\text { ne jeho další úpravy apod.) }\end{array}$} \\
\hline$B Y-N D$ & Uved'te původ - Nezpracovávejte \\
\hline$B Y-N C-N D$ & Uved'te autora - Nevyužívejte komerčně - Nezpracovávejte \\
\hline
\end{tabular}

V̌̌echny CC licence mají společné tyto charakteristiky:

- $\quad$ Licence dovolují dílo šírit (i když za různých podmínek).

- Licence vyžadují, aby při šíření díla nebo jeho zpracování byly uvedeny údaje o díle (autor, název díla, url odkaz na dílo a na podmínky licence, apod.)

- Při šíření díla je nutno připojit URL odkaz na CC licenci. 


\section{PŘÍlOHA 4 - Publikace autorů k diskutované problematice (od roku 2004)}

- Dlouhá, J. a kol. (2012) Metodika tvorby textů v otevřeném internetovém prostoru (schváleno MŽP ČR 31.1.2012, pod č.j. 5782/ENV/12; 154/320/12). Retrieved from: http://www.enviwiki.cz/wiki/Metodika tvorby text\%C5\%AF v otev\%C5\%99en\%C3\%A9m internetov\%C3\%A9m_prostoru

- Dlouhý, J., Dlouhá, J. (2012) Wiki strategies for a more participatory learning environment in Czech education. 11th European Conference on e-Learning ECEL-2012, University of Groningen, Groningen, The Netherlands, 26-27 October 2012,

- Dlouhá, J., Dlouhý, J., Zahradník, M. (2011) Procesy a přístupy k učení - hodnocení práce studentů ve wiki prostředí. In Sojka, P., Kvizda, M. (eds.) Sborník 7. ročníku konference o elektronické podpoře výuky SCO 2011. : 2011. s. 75-80. ISBN 978-80-210-5528-5

- Dlouhý, J., Dlouhá, J. (2011) Výuka v otevřeném virtuálním prostoru - Wikipedie, nebo vlastní wiki? In Sborník 7. ročníku konference o elektronické podpoře výuky SCO 2011. : 2011. s. 81-86 ISBN 978-80-210-5528-5

- Dlouhá, J., Dlouhý, J., Barton, A. (2011) E-learning Methodology for Regional Cooperation and Promotion of the European Learning Space in the Interdisciplinary Field of Sustainable Development. In: Barton, A., \& Dlouhá, J., (eds) Multi-Actor Learning for Sustainable Regional Development in Europe: A Handbook of Best Practice. Guildford: Grosvenor House Publishing Ltd. pp. 81-105

- Dlouhá, J., Dlouhý, J., Barton, A. (2010) Evaluating educational Outcomes in the Interdisciplinary Field of Sustainable Development: Case Study of an E-learning Course in an Interactive (Open) Virtual Space. Knowledge Collaboration \& Learning for Sustainable Innovation \& ERSCP-EMSU conference, Delft, The Netherlands, October 25-29, 2010

- Dlouhá, J., Dlouhý, J., Barton, A. (2010) Use of Web 2.0 Tools for Active Learning Strategies in the Interdisciplinary Field of Sustainable Development: Analysis of Communicative Aspects of Interactive (Open) Virtual Spaces. Engineering Education in Sustainable Development 201019 - 22 September, Goteborg

- Dlouhá, J., Dlouhý, J. (2009). Use of Wiki Tools for Raising the Communicative Aspect of Learning. In: Remenyi D. (ed.) Proceedings of the 8th European Conference on e-Learning. Reading, NR Reading: Academic Conferences Ltd. 165-173 ISBN 978-1-906638-52-8, Kód UT-ISI: 000280732200020

- Dlouhá, J., Dlouhý, J., Pachmanová, L. (2009) E-learning na bázi spolupráce dvou elektronických prostředí - LMS a wiki. Využití EnviWiki, elektronické encyklopedie o životním prostředí, ve vysokoškolské výuce. In: Sojka, P., Rambousek, J. (ed.) Sborník 6. ročníku konference o elektronické podpoře výuky SCO2009. Brno, MUNIpress. 2009, ss. 238-243. ISBN 978-80-210-4878-2

- Dlouhá, J., Dlouhý, J., Macháčková Henderson, L., Zahradník, M. (2009) Wiki Software and Educational Principles of Communicative Action. Case study of the Czech electronic environmental encyclopedia (EnviWiki). E-learning conference: Boundary 
Changes: Redefining Learning Spaces, April 23-24, 2009, University of Plymouth, GB, see http://www2.plymouth.ac.uk/e-learning/conference_programme_2009.pdf

- EnviWiki - encyclopaedia \& environment for active learning strategies and mutual communication (teachers, students, experts). (2009) In: Helen Beetham, Lou McGill, Allison Littlejohn. Thriving in the 21st century: Learning Literacies for the Digital Age (LLiDA project). Excellent practice page [Online] [2009-03-20] Available from www: <http://www.caledonianacademy.net/spaces/LLiDA/index.php? $n=$ Main. CharlesUniversityEnvironmentCentre>

- Dlouhá, J. (2008): EnviWiki - the Czech Multimedia Toolkit for Education for Sustainable Development (ESD). Envigogika, 3(1). [Online] [Citováno 2014-08-29]. Dostupné z http://www.envigogika.cuni.cz/index.php/Envigogika/article/view/373 ISSN: 1802-3061. DOI: http://dx.doi.org/10.14712/18023061.373

- Dlouhá, J. (2007) Environmental Literacy in Theory and Practice. EnviWiki - the Czech multimedia Toolkit. Context of its origin and derived reflections. In: HYTÖNEN, J. Education for Democracy as a Part of Education for Sustainable Development. Helsinki: University of Helsinki. 2007. p. 17-30 ISBN 978-952-10-38570 ; ISSN 1795-2158.

- Dlouhá, J. (2007): EnviWiki - multimediální výuková pomůcka a související reflexe. In: Činčera, J. (ed.) Sborník konference a workshop „Environmentální výchova: nové cesty". 11.-13. 9. 2006, Liberec : Technická univerzita Liberec. str. 20-31 ISBN 978-80-7372-164-0

- Dlouhá, J. (2006). EnviWiki - výuková pomůcka na principu hypertextu Envigogika, 1(1). Dostupné z http://www.envigogika.cuni.cz/index.php/Envigogika/article/view/80 ISSN: 1802-3061. DOI: http://dx.doi.org/10.14712/18023061.80

- Dlouhá, J. (2006): Environmentální gramotnost v teorii a praxi. Př́spěvek - konference a workshop „Environmentální výchova - nové cesty". 11.-13. 9. 2006, Sedmihorky.

- Dlouhá, J. (2006): Environmental Literacy in Theory and Practice. EnviWiki - the Czech multimedia toolkit. Context of its origin and derived reflections. International Journal of Teacher Education and Training.

- Dlouhá, J. (2006): Wikipedia and ESD. EnviWiki - Czech Enviroliteracy Web. Konference UNESCO - Teacher Education Reorientation Towards Sustainability Network, Helsinki.

- Dlouhá, J. (2006) EnviWiki. Internetová encyklopedie věnovaná vzdělávání zaměřenému na prostředí. [online] Datum poslední revize 14.3.2006 [citováno dne 2006-03-14]. http://www.czp.cuni.cz/enviwiki/

- Dlouhá, J. (2005) „Multimediální učebnice pro environmentální vzdělávání; návaznost na mezinárodní aktivity"; Oponovaná zpráva projektu Fondu rozvoje vysokých škol v tematickém okruhu 1124/2005, TO: Be.

- Dlouhá, J. (2004): Multimediální podoba vzdělávání pro udržitelný rozvoj. In: Sborník mezinárodní konference UNESCO Teacher and Education for Sustainable Development, Učitel a vzdělávání pro udržitelný rozvoj. Čermák Publishers, Praha. str. 167-171. 